\title{
Analysis and selection of experimental models of osteoarthritis
}

\author{
Zaporozhye State Medical University \\ Key words: Osteoarthritis, Pathogenesis, Experimental animal model, Articular cartilage, Subchondral bone.
}

\begin{abstract}
Aim. The aim of the work is to examine relevant literature on different patterns of experimental osteoarthritis and choose the most acceptable one for providing its preclinical investigation.

Methods and results. Osteoarthritis (OA) is one of the common forms of joint disease. OA is mainly in the head of the top five causes of disability. Notwithstanding a great number of revealed predisposing factors and the involvement of mechanical distress, the exact pathogenesis of OA is still a subject of investigation. Particularly the earliest changes are largely unknown, because they appear long before clinical manifestation, and that is why they are not able to be studied in humans. The great number of OA researches is devoted to the methods of early detection and developing strategies of its treatment. Animal experimental models help in investigating mechanisms of OA development and finding morphological, physiological criteria for strict diagnosis of OA.

Conclusion. It was settled that small animal experimental models of OA are more suitable for preclinical investigations of OA pathogenesis: its genetic and molecular mechanisms; large animal experimental models of OA allow to investigate biomechanical changes of the joint and to provide intraarticular interventions. Methods which are necessary for perfect investigation of the joint are also described in the article.
\end{abstract}

\begin{abstract}
Аналіз і вибір експериментальної моделі остеоартрозу
О. А. Григор'єва, О. В. Моніна, Е. Р. Скаковський

Особливу увагу приділяють нині виявленню та вивченню ранніх змін у структурах суглоба (суглобовому хрящі, суглобовій капсулі, субхондральній кістці), які з'являються до маніфестування клінічних симптомів, що не можливо вивчити на людині. Мета роботи полягала в аналізі відомостей сучасної фахової літератури щодо окремих експериментальних моделей остеоартрозу на лабораторних тваринах й описі найбільш прийнятної моделі для виконання морфологічного дослідження. Встановили, що експериментальні моделі остеоартрозу з використанням невеликих лабораторних тварин (щури, мурчаки, миші, кролі) оптимальні для вивчення генетичних і молекулярних основ патогенезу остеоартрозу. Експериментальні моделі остеоартрозу 3 використанням великих лабораторних тварин (собаки, свині тощо) оптимальні для вивчення біомеханічних особливостей реактивності суглобів та виконання внутрішньосуглобових втручань.
\end{abstract}

Ключові слова: остеоартроз, етіологія, експериментальна модель, суглобовий хрящ.

Патологія. - 2014. - №2 (31). - C. 12-15

\section{Анализ и выбор экспериментальной модели остеоартроза}

\section{Е. А. Григорьева, Е. В. Монина, Э. Р. Скаковский}

Особое внимание сегодня уделяют установлению и изучению ранних изменений в структурах сустава (суставном хряще, суставной капсуле, субхондральной кости), предшествующих появлению клинических симптомов, которые невозможно изучить у человека. Цель работы - проанализировать данные современной специализированной литературы о различных моделях экспериментального остеоартроза на лабораторных животных и выбрать наиболее приемлемую модель для морфологического исследования. Установлено, что экспериментальные модели остеоартроза с использованием мелких лабораторных животных (мыши, крысы, морские свинки, кролики) оптимальны для изучения генетических и молекулярных основ патогенеза остеоартроза. Экспериментальные модели остеоартроза с использованием крупных животных (собаки, лошади, овцы, свиньи) оптимальны для изучения биомеханических особенностей реактивности сустава, проведения внутрисуставных вмешательств.

Ключевые слова: остеоартроз, этиология, экспериментальная модель, суставной хрящ.

Патология. - 2014. - №2 (31). - С. 12-15

$\mathrm{B}$ ones and joints diseases are one of the most common causes for severe long-term pain and prolonged disability (Chen, 2012). In the United States OA affects $13,9-33,6 \%$ of adults or approximately 27 million Americans of all ages (Lawrence, Felson, Helmick et al., 2008; Gregory et al., 2012). Pain, joint stiffness and reduced motion lead to disability and loss of independence of patients with OA. Global cost of osteoarthritis increases. According to this situation, the World Health Organization proclaimed the Bone and Joint Decade (2000 - 2010) in order to advance understanding and treatment of joint diseases by means of prevention, education and research.

Osteoarthritis (OA) is one of the common forms of joint diseases. It is usually considered as a part of the aging process (Bondeson et al., 2010). It is a group of chronic, painful, disabling conditions affecting synovial joints. It is possible to define primary OA, which develops without any predisposal factors and secondary OA when the patient suffered from any traumatic injury (Sakkas and Platsoucas, 2007). Secondary OA is a mechanically induced disorder in which the consequences of abnormal joint mechanics provoke biological effects that are mediated biochemically. OA usually develops when the mechanical stresses on the normal joint are excessive, or in the case of metabolic abnormalities of the joint (Brandt K. D., Radin E. L., Dieppe P. A. \& van de Putte L., 2006; Sakkas and Platsoucas, 2007). 
It is characterized by the complex of joint disorders. Among risk factors obesity, trauma and other mechanical factors are revealed (Bondeson et al., 2010). However, it is impossible to forget about certain endogenous factors, such as type II collagen mutations, acetabular dysplasia, osteogenesis imperfecta, some other genetic, hormonal and immunological ones (Bondeson et al., 2010).

Nowadays, OA is not only a disease of old persons (Bondeson et al., 2010), but it appears even in adolescents and children as one of the manifestations of the hypermobility syndrome (Kaissi, Klaushofer \& Grill, 2009). Influence of different factors during the intranatal period of ontogenesis results in primary functional immaturity of articular cartilage, which is one of the main causes of destructive and dystrophy changes of joints after birth (Григор'єва O.А., Волошин М.A., 2011). While investigation of mothers' katamnesis of children with diagnosed undifferentiated connective tissue dysplasia, gestosis syndrome of the first and second part of pregnancy was revealed. Hormonal, immunological, endocrine disorders in fetal period were also diagnosed in such cases.

Modern View on OA Etiology and Pathogenesis

$\mathrm{OA}$ is a systemic multiple etiological musculoskeletal disease (Sakkas and Platsoucas, 2007). Notwithstanding a great number of revealed predisposing factors and the involvement of mechanical distress, the exact pathogenesis of OA is still a subject of investigation. Particularly, the earliest changes are largely unknown, because they appear long before clinical manifestation, and that is why they are not able to be studied in humans.

In the case of OA, the whole joint is impaired, its lesion is associated with irreversible articular cartilage loss, concomitant sclerotic changes in the subchondral bone, destruction of the articular capsule, synovitis, and appearance of osteophytes. Articular cartilage has been the focus of research into OA for decades; it is affected predominantly in OA. This affection is mainly connected with gradual loss of extracellular matrix, composed mainly of aggrecan and type II collagen. Impaired synthesis of collagen II can result in development of OA (Blair-Levy et al., 2008). Loss of aggrecan decreases cartilage compressive stiffness and leads to the damaging of collagen febrile network (Goldring M.B., Marcu K.B.).

Different types of collagen are distinguished in the contents of the extracellular matrix of the articular cartilage. Type II collagen forms about $90 \%$ of the fibers in the mature articular cartilage. Proportion of different types of collagen changes with age and under different pathological conditions, and needs further examination. Very little, however, is known about the mechanisms and role of the extracellular matrix and its interactions with cell receptors in the regulation of mineralization events of chondrocytes. Binding of type II collagen and/or type $\mathrm{X}$ collagen to annexin V stimulates its $\mathrm{Ca}^{2+}$ channel activities, leading to an influx of extracellular $\mathrm{Ca}^{2+}$ ions into chondrocytes. Annexin $\mathrm{V}$ is expressed in human osteoarthritic cartilage, but not in healthy human articular cartilage. Type X collagen expression was also detected in human osteoarthritic cartilage, suggesting hypertrophic and terminal differentiation events occur in articular cartilage during osteoarthritis (Kim and Kirsch, 2008).

Tide mark, which consists of proteoglycans, provides elasticity of the mature articular cartilage (Goldring M.B., Marcu K.B.). Its thickness and contents change in OA which brakes biochemical and biomechanical barrier between subchondral bone and articular cartilage; therefore, it is followed by cartilage destruction. Vascular pathology also plays a leading role in the initiation and progression of OA. Vascular invasion of the calcified cartilage from the subchondral bone is one of the early factors in the progression of the disease (Findlay, 2007). Correlation between proinvasive and antiinvasive factors in OA has not been determined yet and needs further investigation.

Subchondral bone is the next «violin» in OA development. The subchondral bone is not only a structural support for articular cartilage, but it also necessary for biochemical interaction between the articular cartilage and bone. Vascularity of the subchondral bone is altered with increasing severity of OA. Sclerosis of the subchondral bone, its stiffness, and formation of cysts within it are the morphological changes of the subchondral bone in OA (Mastbergen and Lafeber, 2011).

$\mathrm{OA}$ is also characterized by a broad spectrum of changes in the synovial membrane, ranging from small infiltration of the synovial membrane with lymphocytes and macrophages to intense infiltration, thickness of the vascular wall and general edema of the articular capsule. That is, it is impossible to say, that OA is only a degenerative joint disease (Sakkas and Platsoucas, 2007). Synovial inflammation aggravates symptoms of OA. In fact, OA synovial macrophages exhibit an activated phenotype; they produce vascular endothelial growth factor and proinflammatory cytokines, such as TNF- $\alpha$, IL-1, IL-10, matrix metalloproteinases, and tissue inhibitors of metalloproteinases (Bondeson et al., 2010). According to lymphocytes, the two main different populations are distinguished in the synovial membrane: residual with $\gamma / \delta \mathrm{TCR}^{+} \mathrm{T}$ cells, which fulfill morphogenic function and control over the proportion of different cell types, range of proliferation; the second population takes part in a $\mathrm{T}$ cell immune response, they express activation antigens, Th1 cytokines (Sakkas and Platsoucas, 2007). Dynamics of lymphocytes, their phenotype, and their role in OA development are worth investigating.

\section{Directions of $O A$ Researches}

The great number of OA researches is devoted to the methods of early detection and developing strategies of its treatment. It is impossible to analyze the development of the human joint in normal conditions and under the influence of different factors during the fetal period of development, because of many bioethical problems, great number of attendant pathology etc. It is also impossible to analyze molecular mechanisms of OA development in patient in dynamics. So, it is necessary to investigate these processes on experimental animal models with further extrapolation of obtained data. Animal experimental models help in investigating mechanisms of OA development and finding morphological, physiological criteria for strict diagnosis of OA. 
In some animal models, more advanced stages of OA can be studied. It is often considered that experimental animal research is necessary for the treatment of human diseases, but not all the animal models are adequate for clinic. Some methodological problems of animal experiments, such as nuances in laboratory technique that may influence on the results etc., still exist (Mastbergen and Lafeber, 2009).

\section{Methods}

A comprehensive review of the English language literature was performed using electronic databases Medline (20052013), CINAHL (2007-2013), and ProQuest (2007-2013). The following search terms were used in different combinations: «Osteoarthritis», «Experimental models of OA», «Intraarticular changes», and «Pathogenesis of OA». The lists of references of the chosen articles were also analyzed.

\section{Results}

To study the changes associated with cartilage, subchondral bone and synovial membrane impairment during $\mathrm{OA}$ numerous animal models have been developed and proposed. For this purpose, different types of animals are used: mouse, rat, dog, horse, sheep, goat, guinea pig, etc. It is important to remember that translation of knowledge from animal models to humans should be done with caution (Gregory et al., 2012).

Experimental animal models of osteoarthritis induction include some ones, based on intraarticular injections of different solutions such as sodium monoiodoacetate, Escherichia Coli Lipopolisacharide, etc. These models were developed on the eve of OA investigation. Later on traumatic impact models, instability-based models were proposed.

Unfortunately, a single gold standard model for OA is steel absent. Each model is characterized by its own unique advantages and disadvantages. It is necessary to take into consideration age, size, and sex of the animals. Small animals (mice, rats, guinea pigs, rabbits) are suitable because of their easy upkeep, low cost, and genetic manipulations. So, small animal models are most advantageous for investigation of specific disease mechanisms, preclinical initial screening of therapeutics. They, especially mouse models, are useful in elucidating the genetic (for example, Kniest and Sickler syndrome) and molecular pathogenesis of OA (Gregory et al., 2012). In the case of morphological examination of joint, in general, these models are also favorable, because of the size of the joint. Consequently, it is possible to make one histological sample, which includes all the components of the joint - articular capsule, articular cartilage, subchondral bone, menisci and intraarticular ligaments. That makes possible to have a glance on changes of the joint in the whole. It allows examining quantitative and qualitative composition of cells and substances of the extracellular matrix of all the components of the joint. Mouse experimental models for a long time were the pioneers in biomedical animal models. The Brtl (a knockin model of human osteogenesis imperfecta) mouse model demonstrates that destruction of articular cartilage is secondary to altered architecture of the subchondral bone (Blair-Levy et al., 2008).

Hartley guinea pigs spontaneously develop degenerative changes of articular cartilage that are similar to established in humans. Guinea pig model of OA helped in the description of subchondral sclerosis as a biphasic process, characterized with primary thickness of the subchondral bone, which is followed by its stiffness (Muraoka et al., 2007).

Rabbit experimental instability model of OA is one of the most widely used experimental models of OA; it means transection of the anterior cruciate ligament. It is of particular clinical relevance to posttraumatic OA in humans (Tiraloche, Girard, Couinard, Sampalis, Moquin, Ionescu, Reiner, Poole \& Laverty, 2005).

Large animal models of OA induction are most advantageous in biomechanical and anatomical similarity to humans, ability to use routine diagnostic imaging, capabilities for arthroscopic interventions and postoperative management. They (dogs, pigs, goats, horses etc.) can undergo routine MRI in vivo to analyze cartilage volume, bone marrow lesions, synovitis, lesions of the ligaments and menisci (Roemer, Crema, Trattnig \& Guermazi, 2011). And vice versa mice, rats, guinea pigs are too small for MRI (Blair-Levy et al., 2008). As for horses: spontaneous OA is a quite common problem for them. The most frequently affected joint is the metacarpophalangeal joint. In sheep, goats as well as in horses, it is possible to analyze many detailed outcome measures, because of the size of the joints (Mastbergen and Lafeber, 2009).

It is necessary to remember that all animal research must be described in an Animal Care and Use Committee Protocol Form, which must be approved by the institutional Animal Care and Use Committee prior to any animal work being performed. To clarify OA pathogenesis, it is necessary to examine metabolism of articular cartilage, articular capsule and subchondral bone in OA development.

Methods, which are necessary for perfect investigation of the joint

For the investigation of a joint in the whole micro-magnetic resonance imaging and micro-computed tomography are necessary.

For the articular cartilage: 1) macroscopic cartilage assessment: examination of the articular cartilage for gross morphologic changes with application of India Ink; 2) histologic assessment of cartilage: fixed in $10 \%$ neutral buffered formalin, decalcified tissue blocks, dehydrated through graded alcohol, embedded in paraffin 5-6 micrometer sections are stained with hematoxylin-eosin, Safranin O - Fast Green for general review of the cartilage; for estimation of the chondrocytes' density, for analyzing of nucleo-cytoplasmic proportion; chondrocyte necrosis, fibrillation of matrix, fissure or fracture of cartilage, cartilage thinning, chondrocyte clusters and clones, cartilage erosion; 3) immunohistochemical analysis of type I collagen, type II, type IX and type X collagen with relevant positive and negative control; 4) immunohistochemical analysis of VEGF $\alpha$ - for examination of vascular invasion; 5) immunohistochemical analysis of MMP - for investigation of the level of cartilage degradation; 6) staining of the sections with alcyan blue with different concentration of $\mathrm{MgCl}_{2}$ - for cartilage glycosaminoglycans analysis. 
For the subchondral bone: 1) bone mineralization analysis; 2) analysis of subchondral bone thickness on the histological sections using individual point-to-point distance measures; 3) analysis of bone connectivity; 4) analysis of the subchondral bone structure: trabecular bone volume/total volume, trabecular thickness, trabecular number, trabecular separation, subchondral osteonecrosis, osteosclerosis, subchondral bone erosions, and subchondral cyst formation.

For the articular capsule and synovial layer: 1) staining of the sections with hematoxylin-eosin, resorcin - new fuchsin, with Mallori solution, impregnation of the sections with argentum carbonate; 2) immunohistochemical analysis of type I collagen, type III collagen with relevant positive and negative control; 3) immunohistochemical analysis of $\alpha / \beta$ $\gamma / \delta$ T cells, CD3, CD4, CD8, CD25, CD45RO, CD69; 4) immunohistochemical analysis of CD68+ macrophages; 5) immunohistochemical analysis of CD34 in order to reveal endothelial reaction; 6) analysis of articular capsule and synovial layer structure: thickened tissue, villous proliferation, synovial cell hyperplasia, edema, metaplastic changes etc. Statistical analyses have to be the last step in investigation.

\section{Conclusion}

Osteoarthritis (OA) is one of the common forms of joint disease. OA is mainly in the head of the top five causes of

\section{References}

1. Aspden, R. M. (2008). Osteoarthritis: Problems of Growth Not Decay? Rheumatology, 47 (10), 1452-1460. doi: 10.1093/ rheumatology/ken 199

2. Blair-Levy, J. M., Watts, C. E., Fiorientino, N. M., Dimitriadis, E. K., Marini, J. C., \& Lipsky, P. E. (2008). A type I collagen defect leads to rapidly progressive osteoarthritis in a mouse model. Arthritis \& Rheumatism, 58(4), 1096-1106. doi: 10.1002/art.23277.

3. Bondeson, J., Blom, A. B., Wainwright, S., Hughes, C., Caterson, B., \& van den Berg, W. B. (2010). The Role of Synovial Macrophages and macrophage-Produced Mediators in Driving Inflammatory and destructive Responses in Osteoarthritis. $A r$ thritis \& Rheumatism, 62(3), 647-657. doi: 10.1002/art.27290

4. Brandt, K. D., Radin, E. L., Dieppe, P.A., \& van de Putte L. (2006) Yet more evidence that osteoarthritis is not a cartilage disease. AnnRheumDis, 65, 1261-1264. doi:10.1136/ard.2006.058347.

5. Chen, A., Gupte, C., Akhtar, K., Smith, P. \& Cobb, O. (2012). The Global Economic Cost of Osteoarthritis: How the UK Compares. Arthritis, 2012, 1-6. doi:10.1155/2012/698709.

6. Chillemi, C., \& Franceschini, V. (2013). Shoulder Osteoartritis. Arthritis, 2013, 11. doi:10.1155/2013/3.

7. Findlay, D. M. (2007).Vascular pathology and osteoarthritis. Rheumatology, 46, 1763-1768.

8. Goldring, M. B., \& Marcu, K. B. (2009).Cartilage homeostasis in health and rheumatic diseases. Arthritis Research \& Therap., 11(3), 224. doi:10.1186/ar2592.

9. Gregory, M. H., Capito, N., Kuroki, K., Stoker, A. M., Cook, J. L. \& Sherman, S. L. (2012). A review of Translational Animal Models for Knee Osteoarthritis. Arthritis, 2012, 14. doi:10.1155/2012/764621

10. Kaissi, A. A., Klaushofer, K., \& Grill, F. (2009). Osteochondritis Dissecans and Osgood Schlatter Disease in a Family with Stickler Syndrome. Pediatric Rhematology, 7(1), 4. doi:10.1186/1546-0096-7-4.

11. Kim, H. J., \& Kirsch, T. (2008). Collagen/Annexin V Inter- disability. Pain, joint stiffness and reduced motion lead to disability and loss of independence of patients with OA. Notwithstanding a great number of revealed predisposing factors and the involvement of mechanical distress, the exact pathogenesis of OA is still a subject of investigation. Particularly, the earliest changes are largely unknown, because they appear long before clinical manifestation, and that is why they are not able to be studied in humans. The great number of OA researches is devoted to the methods of early detection and developing strategies of its treatment. Animal experimental models help in investigating mechanisms of OA development and finding morphological, physiological criteria for strict diagnosis of OA. In some animal models, more advanced stages of OA can be studied. Small animal experimental models of OA are more suitable for preclinical investigations of OA pathogenesis: its genetic and molecular mechanisms. Large animal experimental models of OA allow to investigate biomechanical changes of the joint and to provide intraarticular interventions. Providing profound preclinical investigations of $\mathrm{OA}$ pathogenesis and treatment is of great importance, because of its great influence on the process of OA development understanding and prevention.

actions regulate chondrocyte mineralization. J. Biol. Chem., 283(16), 10310-10317. doi: 10.1074/jbc.M708456200.

12. Lawrence, R. C., Felson, D. T., Helmick, C. G., et al. (2008). Estimates of the prevalence of arthritis and other rheumatic conditions in the United States Part II, Arthritis \& Rheumatism, 58(1), 26-35. doi: 10.1002/art.23176.

13. Masbergen, S. C., \& Lafeber, F. P. J. G. (2009). Animal Models of Osteoarthritis -Why Choose a Larger Model? Mastbergen US Cardiology book, temp 20/11/2009, 11-14.

14. Masbergen, S. C., \& Lafeber, F. P. J. G. (2011). Changes in Subchondral Bone Early in the Development of Osteaarthritis. Arthritis \& Rheumatism, 63(9), 2561-2563.

15. Muraoka, T., Hagino, H., Okano, T., Enokida, M., \& Teshima, R. (2007). Role of Subchondral Bone in Osteoarthritis Development. Arthritis \& Rheumatism, 56(10), 3366-3374. doi: 10.1002/art.22921.

16. Pound, P., Ebrahim, S., Sandercock, P., Bracken, M. B. \& Roberts, I. (2004). Where is the evidence that animal research benefits humans? BMJ, 328, 514-517.

17. Roemer, F. W., Crema, M. D., Trattnig, S., Guermazi, A (2011). Advances in Imaging of Osteoarthritis and Cartilage. Radiology, 260(2), 332-354. doi: 10.1148/radiol.11101359.

18. Sakkas, L. I., \& Platsoucas, C. D. (2007). The role of T Cells in the Pathogenesis of Osteoarthritis. Arthritis \& Rheumatism, 56(2), 409-424. doi: 10.1002/art.22369.

19. Tiraloche, G., Girard, C., Couinard, L., Sampalis, J., Moquin, L, Ionescu, M., Reiner, A., et al. (2005). Effect of Oral Glucosamine on Cartilage Degradation in a Rabbit Model of Osteoarthritis. Arthritis \& Rheumatism, 52(4), 1188-1128.

20. Hruhorieva, O. A., \& Voloshyn, M. A. (2011). Eksperymentalne modeliuvannia nedyferenciiovanoi dysplazii spoluchnoi tkanyny shliakhom porushennia antuhennoho homeostasu $\mathrm{v}$ systemi maty - platsenta - plid. [Experimental modeling of undifferentiated connective tissue dysplasia by instituting antigenic homeostasis in the mother-placenta-fetus]. Patolohia, 8(2), 39-42. [in Ukrainian].

\section{Information about authors:}

Grygorieva O. A., associated professor, Department of normal anatomy, operative surgery and topographic anatomy, Zaporozhye State Medical University, E-mail: mstesha@mail.ru.

Skakovsky E. R., associated professor, Department of normal anatomy, operative surgery and topographic anatomy, Zaporozhye State Medical University.

Monina O. V., intern, Zaporozhye State Medical University. 